Quebec Cooperative Study

of Friedreich's Ataxia

\title{
Correlation Between Serum Lipoamide Dehydrogenase Activity and Phosphatidylcholine Therapy in Friedreich's Ataxia
}

\author{
S.B. MELANÇON, G. FONTAINE, G. GEOFFroy, M. VANASSE, L. DALLAIRE, M. POTIER
}

SUMMARY: Serum lipoamide dehydrogenase activity and kinetics were studied in nine patients with Friedreich's ataxia before and three months after therapy with oral lecithin. Results disclosed a significant reduction in $L A D$ inhibition by $N A D H$ in all patients after therapy. Three patients normalized their increased $\mathrm{Km}$ for lipoamide and one patient showed the opposite results after therapy. Two pa-

RÉSUMÉ: Nous avons étudié les constantes d'affinité et les vélocités maximales de l'enzyme lipoamide déhydrogénase dans le sérum de neuf patients atteints de l'Ataxie de Friedreich et traités à la lécithine. Deux patients se sont retirés de l'étude après un mois à cause du peu d'effet de la médication. Les sept autres patients ainsi qu'un huitième cas étudié plus tardivement, ont manifesté une amélioration subjective et objective de leur résistance physique après trois mois de traitement. Nous avons observé une tients ceased lecithin after one month. All seven patients who remained in the trial group and one additional patient, showed subjective and objective signs of improvement in physical resistance. This study has offered some biochemical basis for the apparent clinical improvement in patients with Friedreich's ataxia who undergo lecithin therapy.

normalisation du Km lipoamide chez trois d'entre eux et une élévation anormale de ce paramètre chez un quatrième. Tous les patients qui ont terminé l'épreuve thérapeutique avaient aussi normalisé leur niveau élevé d'inhibition de la LAD sérique par le NADH.

C'est donc la première fois que des mesures biochimiques viennent supporter des critères cliniques subjectifs dans l'évaluation de l'effet de la lécithine dans l'Ataxie de Friedreich.
Posphatidyl choline (lecithin) by mouth, is known to increase serum choline levels more efficiently than choline chloride (Wurtman et al. 1977). The administration of lecithin ( $24 \mathrm{~g} /$ day) was reported by Barbeau (1978) as being effective in improving speech, balance and movement disorders in eight patients with Friedreich's ataxia (F.A.). Clinical improvement with lecithin was assumed to be consecutive to a sequential increase in serum choline, brain choline and finally brain acetyl-choline levels or to the correction of a membrane defect. Physostigmine, a cholinesterase inhibitor which enhances brain acetylcholine levels, has also been reported by Rodriguez-Budelli et al. (1978) to improve ataxia in patients with spinocerebellar disorders with or without pyruvate oxidation defects.

The present study was initiated when some younger patients with F.A. expressed the desire to go on a trial of oral lecithin. We decided to obtain some information on the biochemical effects of lecithin, assuming that any significant increase in the synthesis of acetyl-choline would mean an accelerated utilization of acetyl-CoA radicals and possible changes in the activity of the pyruvate dehydrogenase complex. This hypothesis was based on previous reports by our group (Barbeau et al. 1978 ) and other investigators (Kark et al. 1978) of a defective lipoamide dehydrogenase (LAD), the third component of the pyruvate dehydrogenase complex in patients with F.A. and other F.A.-like forms of familial spino-cerebellar ataxias.

\section{MATERIALS AND METHODS}

Nine patients with Friedreich's ataxia and nineteen healthy subjects 
participated in this study on a voluntary basis. No attempts were made to match patients and controls for age, sex or severity of the disease. The control group was heterogeneous and included seven healthy laboratory technicians or physicians (22 to 37 years of age) and twelve friends or relatives of patients with F.A. (all under 21 years of age, except for two, aged 38 and 39 years) who certified not to have taken "lecithin" before. Fasting serum $(10 \mathrm{ml})$ obtained from controls and patients was frozen at $-80^{\circ} \mathrm{C}$ in one $\mathrm{ml}$. aliquots and assayed within one month for lipoamide dehydrogenase activity (LAD). Repeat serum samples were obtained from seven of the nine original patients and one additional patient after three months on oral phosphatidyl choline (lecithine, LALCO, Ltd. Montréal) at a dose of $3.2 \mathrm{~g}$ three times a day. Four patients were also available for blood sampling one month after the start of lecithin and two of them elected not to pursue their treatment thereafter.

Measurement of LAD activity and kinetic studies were carried out using freshly thawed serum and freshly prepared reagents as previously suggested (Melançon et al. 1978b). Standard runs using freshly thawed serum from the same control individual were made before every determination of LAD activity. Optical density readings averaged $.039 \pm .003$ units/ $10 \mathrm{~min} / 0.05 \mathrm{ml}$ of serum (Range, $.032-.044)$ for a total of forty LAD determinations over a period of three months. Total LAD activity in serum was determined according to Pelley et al. (1976). Kinetic studies were performed using lipoamide at concentrations of $0.4 \mathrm{mM}$ to $6 \mathrm{mM}$ and NAD at concentrations of $0.05 \mathrm{mM}$ to $3.0 \mathrm{mM}$. Inhibition of LAD activity by added $\mathrm{NADH}$ (Ki) was estimated with $\mathrm{NADH}$ at concentrations of $0.1 \mathrm{mM}$ to $0.4 \mathrm{mM}$. Michaelis-Menten constants $(\mathrm{Km})$ were calculated by linear regression from the linear portion of Lineweaver-Burk plots. Maximal enzyme velocities (Vmax) were determined in the same manner and for the purpose of illustration, were reported in optical density units (O.D.). Conversion into LAD U/liter of serum was done by multiplying the O.D. by $322 \mathrm{x}$ $10^{3}$.
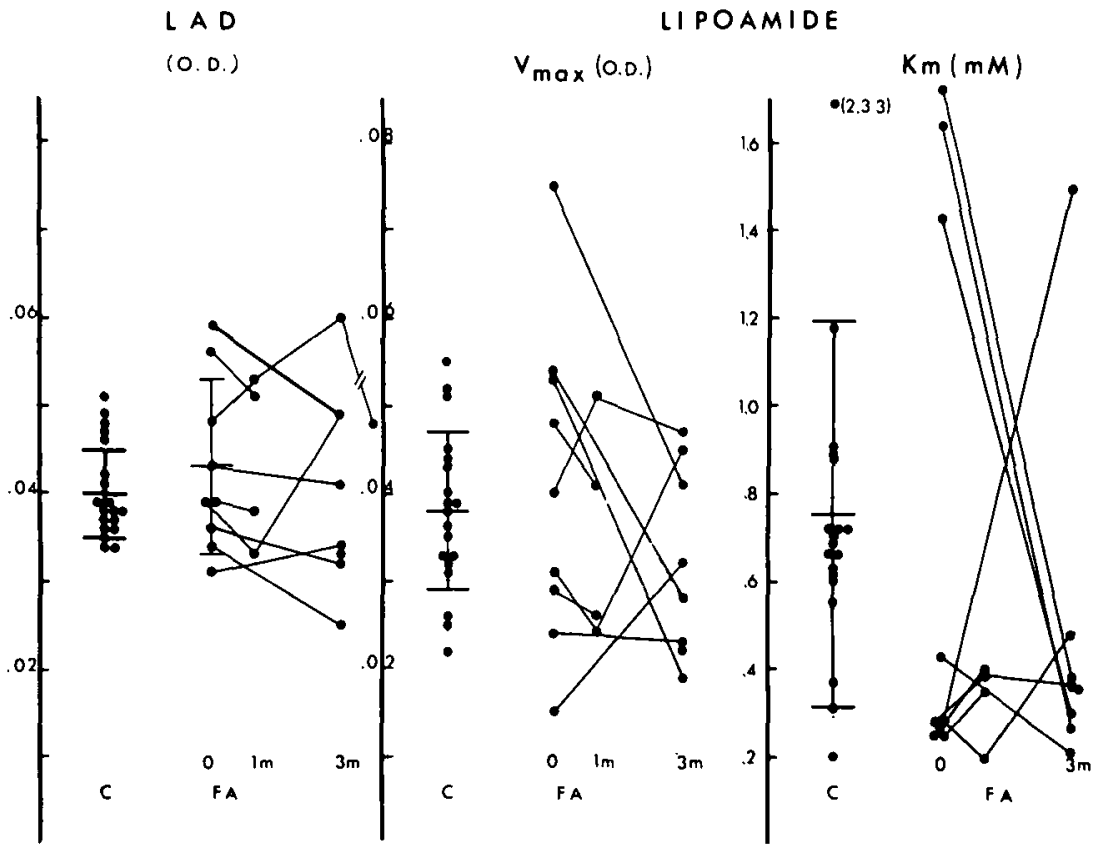

Figure I - LEFT: Serum LAD activity (O.D. units) in 19 controls and 9 patients with Friedreich's Ataxia (F.A.) before (o) and 3 months $(3 \mathrm{~m})$ after oral lecithin. CENTER: Maximal velocity (Vmax) of serum LAD for lipoamide (O.D. units) RIGHT: MichaelisMenten constants $(\mathrm{Km})$ of serum LAD for lipoamide $(\mathrm{mM})$

\section{RESULTS}

Seven of the nine patients treated with lecithin reported some degree of clinical improvement. By standard neurological evaluation it was found that these patients had improved their muscular strength and physical resistance in a qualitative rather than quantitative manner. Two patients experienced subjective deterioration after one month of therapy and elected to cease their treatment.

The effects of lecithin on LAD activity and kinetics in serum of patients with F.A. are illustrated in figures 1 and 2 . The most striking effects appeared to be the reduction in $\mathrm{Km}$ and Vmax of LAD towards lipoamide in three patients (fig. I center and right) and the statistically significant reduction in LAD inhibition by NADH (fig. 2 right and table I) in patients with F.A. after three months of lecithin therapy.

The mean activity of LAD in serum as function of age of patient and controls is illustrated in figure 3.

\section{DISCUSSION}

Our results provide some evidence that the subjective clinical improve- ment observed with lecithin in patients with F.A. may occur through biochemical changes other than previously thought. We presume with others (Growdon et al. 1977) that part of the clinical success was due to an improved availability of acetyl-choline from exogenous doses of choline precursor (lecithin). However, we have evidence that lecithin or some unknown metabolite of lecithin displayed some action prior to acetylcholine synthesis and possibly at the enzyme level itself.

The exact origin of LAD in serum is still unknown, although Pelley et al. (1976) provided evidence that liver could account for most of the enzyme recovered in serum. Our kinetic studies on serum and previous work in fibroblasts (Melançon et al. 1978a, b) were not in favor of the presence of more than one component of LAD, as reported for platelets (Kark et al. 1978). However, three of our nine patients displayed higher than control $\mathrm{Km}$ for lipoamide before lecithin and one after lecithin (the only control subject with high $\mathrm{Km}$ for lipoamide was a 38-year-old apparently healthy cousin of two patients with F.A.). 


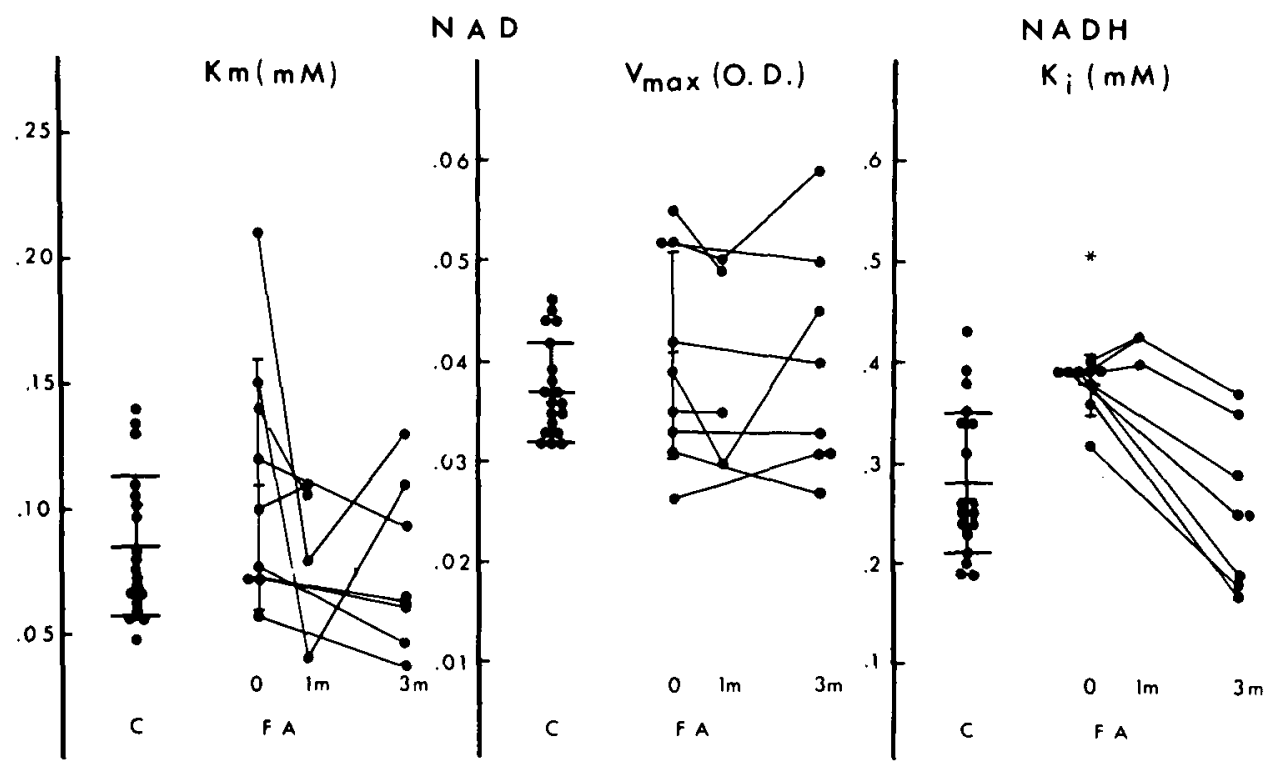

Figure 2 - LEFT: $\mathrm{Km}(\mathrm{mM})$ of serum LAD for NAD in 19 controls and 9 patients with Friedreich's Ataxia (F.A.) before (o) and 3 months $(3 \mathrm{~m})$ after oral lecithin. CENTER: $V \max (O . D$. units) of serum LAD for NAD. RIGHT: Inhibition constants (Ki) of serum LAD by NADH (mM).

These data would be in agreement with the results of Kark et al. (1980) who reported an increased $\mathrm{Km}$ for lipoamide (in platelets) in families of patients with à recessive form of ataxia. However, there is a marked difference between lipoamide $\mathrm{Km}$ values in platelets (low $=.056 \mathrm{mM}$; high $=.147 \mathrm{mM})$ and serum $(.73 \mathrm{mM})$ which prevent us from comparing the results in an adequate way.

The effect of lecithin on LAD inhibition by exogenous NADH cannot be adequately explained at the present time. This decrease in the concentration of NADH necessary to bring out a $50 \%$ lowering in serum LAD activity may be due to factors present in serum

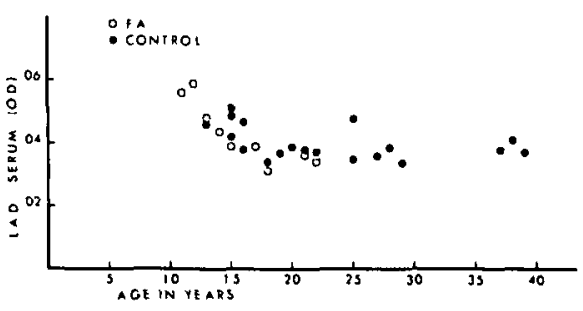

Figure 3 - Age distribution of serum LAD activity in 19 controls and 9 patients with Friedreich's Ataxia (F.A.).

or to enzymatic changes. We have not yet attempted to elucidate the origin of this modification.

Another unexpected finding was disclosed when serum LAD activity were plotted according to age. It was found that serum LAD activity was higher in younger patients with F.A., than in older control subjects. This observation is, however, not incompatible with previous reports of a decreased serum LAD activity (Melançon et al. 1977; Filla et al. 1978) in older patients with F.A. We are presently investigating the effect of lecithin on LAD activity, enzyme kinetics and objective parameters of physical performance in patients with F.A. and age-matched controls in a double-blind study. We hope to be able to answer some of the previously discussed but unresolved questions at the completion of this second study.

\section{ACKNOWLEDGEMENTS}

This work was supported by l'Association Canadienne de l'Ataxie de Friedreich. We thank Solange Lebrun-St-Jacques for her help in obtaining blood samples and Diane Bernard for typing the manuscript.

\section{REFERENCES}

BARBEAU, A. (1978): Emerging treatments: Replacement therapy with choline or lecithin in neurological diseases. Can. J. Neurol. Sci. 5: $157-160$.

BARBEAU, A, MELANCON, S.B., BUTTERWORTH, R.F., FILLA, A., IZUMI, K. and NGO, T.T. (1978): Pyruvate dehydrogenase complex in Friedreich's Ataxia. In Kark RAP, Rosenberg, R.N., Schut, L.J. Eds. Advances in Neurology, vol. 21, 203-217. Raven Press, New York.

FILLA, A., BUTTER WORTH, R.F., GEOFFROY, G., LEMIEUX, B. and BARBEAU, A. (1978): Serum and platelet lipoamide dehydrogenase in Friedreich's Ataxia. Can. J. Neurol. Sci. 5: 111-114.

$* p<0.05$ for difference from controls ( $T$ test of Wetch) and from post-therapy (Student $t$ test). 
GROWDON, J.H., COHEN, E.L. and WURTMAN, R.J. (1977): Effects of oral choline administration on serum and CSF choline levels in patients with Huntington's disease. J. Neurochem. 28: 229-231.

KARK, P.R.A., RODRIGUEZ-BUDELLI, M. and BLASS, J.P. (1978): Evidence for a primary defect of lipoamide dehydrogenase in Friedreich's Ataxia. In Kark RAP, Rosenberg, R.N., Schutt, L.J. Eds. Advances in Neurology, vol. 21, 163-180, Raven Press, New York.

KARK, P.R.A., RODRIGUEZ-BUDELLI, M., PERLMAN. S., GULLEY, W.F., and TOROK, K. (1980): Preclinical diagnosis and carrier detection in ataxia associated with abnormalities of lipoamide dehydrogenase. Neurology 30: 502-508.

MELANÇON, S.B., POTIER, M., DALLAIRE, L., GEOFFROY, G., LEMIEUX, B., and BARBEAU, A. (1977): Serum lipoamide dehydrogenase in Friedreich's Ataxia. Pediat. Res. 11: 460.

MELANÇON, S.B., POTIER, M., DALLAIRE, L., FONTAINE, G., GRENIER, B., LEMIEUX, B., GEOFFROY, G. and BARBEAU, A. (1978a): Lipoamide dehydrogenase in Friedreich's Ataxia fibroblasts. Can. J. Neurol. Sci. 5: 115-118.

MELANÇON, S.B., DALLAIRE, L. and POTIER, M. (1978b): Lipoamide dehydrogenase in cultured human skin fibroblasts.
Clin. Chim. Acta. 87: 29-34.

PELLY, J.W., LITTLE, G.H., LINN, T.C. and HALL, F.F. (1976): Lipoamide dehydrogenase in serum: A preliminary report. Clin. Chem. 22: 275-277.

RODRIGUEZ-BUDELLI, M., PIETER KARK. R.A., BLASS, J.P. and SPENCER, M.A. (1978): Action of physostigmine on inherited ataxias. In Kark RAP, Rosenberg, R.N.. Schutt, L.J. Eds. Advances in Neurology, vol. 21, 195-202, Raven Press, New York.

WURTMAN, R.J., HIRSCH, M.J. and GROWDON, J.H. (1977): Lecithin consumption raises serum-free choline levels. Lancet, 2 : 65-69. 